\title{
SMARCE1 wt Allele
}

National Cancer Institute

\section{Source}

National Cancer Institute. SMARCE1 wt Allele. NCI Thesaurus. Code C52055.

Human SMARCE1 wild-type allele is located in the vicinity of 17q21.2 and is approximately

$37 \mathrm{~kb}$ in length. This allele, which encodes SWI/SNF-related matrix-associated actindependent regulator of chromatin subfamily E, member 1 protein, plays a role in the modulation of both chromatin structure and DNA transcription. 